\title{
Proposal of a framework for product-service systems characterization
}

\author{
Fernanda Hansch Beuren ${ }^{\mathrm{a}, \mathrm{b} *}$, Thayla Tavares Sousa-Zomera, Paulo Augusto Cauchick-Miguel ${ }^{\mathrm{a}}$ \\ aUniversidade Federal de Santa Catarina, Florianópolis, SC, Brazil \\ bUniversidade do Estado de Santa Catarina, São Bento do Sul, SC, Brazil \\ *fernandahansch@yahoo.com.br
}

\begin{abstract}
Product-service systems (PSS) design raises new issues, among which the need of encompassing a life cycle perspective. The aim of this paper is to propose a conceptual framework for PSS characterization through its life cycle. The purpose is to understand the structure, the sequence, and the main characteristics of PSS life cycle phases, characterizing a PSS process model. A systematic literature review was carried out to identify the PSS life cycle phases and the conceptual elements that characterize each phase. The PSS life cycle was structured based on service life cycle from the customer perspective. Afterwards, the conceptual framework was built for PSS characterization considering business model, engineering and design aspects that may be useful to guide PSS solutions development. The paper aims to make a theoretical contribution by understanding what should be done and how to perform the activities during PSS life cycle at a systemic level.
\end{abstract}

Keywords

Product-service systems. PSS. Design. Life cycle management. Conceptual framework.

How to cite this article: Beuren, F. H., Sousa-Zomer, T. T., \& Cauchick-Miguel, P. A (2017). Proposal of a framework for product-service systems characterization. Production, v27, e20170052. http://dx.doi.org/10.1590/0103-6513.20170052

Received: June 26, 2017; Accepted: Oct. 20, 2017.

\section{Introduction}

Product-Service Systems (PSS) have been widely discussed as a promising approach to improve the competitiveness of industrial manufacturers and to reorient the consumption and production patterns (Van Ostaeyen et al., 2013). A PSS is an integrated product and service offering that delivers value in use (Roy \& Baxter, 2009). The concept of a PSS emphasizes that consumers can be satisfied by the service that the products support and the results they obtain (Salazar et al., 2015). A number of sustainable PSS solutions has been discussed in the literature, including bike-sharing systems as a convenient and 'green' transportation mode that plays an important and complementary role in the comprehensive transportation system (Zhang et al., 2015) as well as car-sharing systems (United Nations Environment Programme, 2002), which has been widely discussed for showing positive environmental effects.

The number of publications on PSS as strategies to increase competitiveness and to tackle sustainability issues has been increasing in recent years. However, some research gaps concerning PSS design and implementation remain. The development of a product-service integrated solution raises new issues since the service component introduces further requirements, among which the need of encompassing a life cycle perspective (Cavalieri \& Pezzotta, 2012). PSS is systemic and should be planned considering all stages of its life cycle (Sundin, 2009; Alix \& Zacharewicz, 2012). Moreover, PSS represents a system that embraces products, services a network of actors as well as an infrastructure so that all PSS elements should be considered in an integrated life cycle to satisfy consumers' requirements (Geng et al., 2010). Designing a PSS to enhance the customer experience and satisfaction remains a complex task (Carreira et al., 2013). 
Nevertheless, although approaches for designing PSS through its life cycle are relevant (Tran \& Park, 2016), the PSS life cycle has not been comprehensively discussed in the existing literature (Kim et al., 2016). In fact, few authors (e.g. Aurich et al., 2006; Yang et al., 2010a, b; Wiesner et al., 2015) have been addressing the integrated life cycle of PSS, considering both the life cycle of the physical artifact and the service life cycle. However, one of the dimensions required to develop effective PSS solutions is the full life cycle consideration and representation (Vasantha et al., 2012). Both product life cycle (PLC) and customer activity cycle (CAC) should be considered in PSS design (Nemoto et al., 2015). In this sense, a real integration of the life cycle remains necessary as well as a progressive life-cycles specification process.

Thus, this paper proposes a framework for PSS characterization based on its life cycle. The PSS life cycle was structured based on the literature to provide the basis for the identification of PSS conceptual elements at each life cycle phase. This proposal aims to contribute to the understanding of which are the main characteristics ('hows'), the structure, and the sequence of life cycle phases, characterizing a PSS engineering process model. The remainder of the paper is structured as follows. Section 2 describes the research design to structure PSS life cycle and to build the conceptual framework. Section 3 describes the results of the conceptual model development, by firstly addressing PSS life cycle and afterwards that the conceptual elements involved in each life cycle stage. Finally, concluding remarks are drawn in addition to some insights for future work.

\section{Research design}

This exploratory research is composed of three main phases. Firstly, a theoretical review was carried out (phase 1). This type of review is appropriate to tackle emerging issues that would benefit from the development of new theoretical foundations (Paré et al., 2015), which is the case of PSS design field that lacks a full life cycle representation and consideration (Vasantha et al., 2012). Thus, a literature review was conducted to identify the main relevant papers that address the PSS life cycle phases and the main research gaps concerning the integrated PSS life cycle, which was the basis to structure the PSS life cycle proposed in this work (phase 2). In addition, the literature review was also the basis for the identification of the conceptual elements from the input and output stages of the PSS life cycle to propose a conceptual framework for PSS characterization (phase 3). The paper highlights what it is necessary to take into consideration in each life cycle phase for a business model to be considered a PSS and how it can be analyzed and compared to other PSS solutions.

The literature analysis aimed publications in peer-reviewed journals, covering all subject areas. Papers published between 1999 and 2015 were selected from the following databases: Scopus, ISI Web of Knowledge, Science Direct and Springer Link. A keyword collection was divided into three groups. The first group contains keywords with PSS synonymous and related terms. The papers in the second group had the purpose of recognizing PSS life cycle phases. The third group of publications aimed to spot conceptual elements for PSS characterization. The search was also structured by combining PSS terms, similar to the strings adopted by Baines et al. (2007). The terms were searched in titles, abstracts, and keywords. Table 1 summarizes the results.

Table 1. Initial search results according to the search terms.

\begin{tabular}{lcccc}
\hline \multicolumn{1}{c}{ Keywords } & Scopus & $\begin{array}{c}\text { Web of } \\
\text { Science }\end{array}$ & $\begin{array}{c}\text { Science } \\
\text { Direct }\end{array}$ & $\begin{array}{c}\text { Springer } \\
\text { Link }\end{array}$ \\
\hline $\begin{array}{l}\text { Product-service systems } \\
\text { Servitization }\end{array}$ & 358 & 275 & 276 & 40 \\
Productization & 102 & 89 & 49 & 65 \\
$\begin{array}{l}\text { (product-service systems) and (life cycle or lifecycle) } \\
\text { (product-service systems) and (sustainability } \text { or remanufacturing } \text { or }\end{array}$ & 36 & 14 & 3 & 37 \\
$\begin{array}{l}\text { service design } \text { or service economy } \text { or } \text { product substituting service } \text { or } \\
\text { dematerialization } \text { or system solution } \text { or functional economy) }\end{array}$ & 109 & 51 & 55 & 25 \\
\hline
\end{tabular}

The articles were selected according to the following criteria as defined in the systematic review protocol: (i) addresses PSS life cycle stages both in modeling frameworks and life cycle assessment studies; (ii) discusses PSS business model structure; (iii) proposes PSS design methodologies, frameworks and tools for PSS development, and (iv) focuses on case studies of different PSS categories, since those papers probably address elements that should be considered in a specific PSS offer. Moreover, as a value proposition model with an emphasis on consumer satisfaction by providing functions, PSS has four key elements (Mont, 2002): (i) products; (ii) services; (iii) actors network, and (iv) infrastructure. These elements were also considered for 
conceptual elements identification in each stage of PSS life cycle, especially concerning the development phase. The literature was analyzed by two authors to increase the research reliability.

The knowledge gained during phase 1 (literature analysis) was applied to structure phases 2 and 3 . For the second phase, 124 papers were selected. After reading the titles and abstracts, 19 papers were considered for analysis. The PSS life cycle phases were identified and from the main phases of integrated product-service life cycles discussed in the literature as well as the service and product life cycles, a PSS life cycle was proposed by considering three main life cycle stages: (i) beginning of life (BoL), (ii) middle of life (MoL), and (iii) end of life (EoL).

Based on the inputs and outputs of each life cycle phase, the selected papers in phase 1 were analyzed to identify 'how' to meet the requirements of each life cycle stage, thus obtaining a list of the conceptual elements of each life cycle stage for PSS characterization. The search identified 729 publications. After applying the screening criteria described earlier, 435 papers were taken into account for further analysis. The following questions, based on the PSS life cycle proposed, guided the conceptual elements identification in the content analysis: (i) what are the requirements for a specific PSS type to meet consumers' needs? (ii) how to develop each PSS element to meet the specific requirements of different PSS solutions? (iii) what is necessary to do during the use phase for a PSS be available to consumers use? (iv) what is necessary to be monitored during PSS use phase to improve the system? (v) what are the possible products destination option in the PSS end of life? Next sections present the results of the content analysis carried out. From that analysis, a framework was then proposed, which is described next.

\section{Proposing a conceptual model for PSS characterization}

The construction of the conceptual model is presented in two parts: (i) PSS life cycle development and (ii) conceptual elements identification, which is outlined in next sections.

\subsection{Development of the PSS life cycle}

The literature was analyzed to identify how the PSS life cycle has been addressed in the past research. Table 2 presents the main papers and the life cycle phases discussed in the literature.

Table 2. PSS life cycle phases addressed in previous publications.

\begin{tabular}{|c|c|}
\hline Life cycle phases addressed & References \\
\hline Conception, raw material, production process, distribution, consumption, end of life & $\begin{array}{l}\text { Maxwell \& van der Vorst } \\
\text { (2003) }\end{array}$ \\
\hline Demand identification, feasibility analysis, concept development, service modeling, realization planning, service testing & Aurich et al. (2006) \\
\hline Planning and development, manufacturing the physical product, realization of the corresponding services & Aurich et al. (2009) \\
\hline Manufacturing, maintenance, logistics and remanufacturing & Sundin et al. (2009) \\
\hline Development, manufacturing, realization, provision, use, recycling and end-of-life & Meier et al. (2010) \\
\hline Fabrication, transportation, installation and use & Lelah et al. (2011) \\
\hline Resource, design, manufacturing, sale/distribution, use, maintenance, end of product use & Zhu et al. (2012) \\
\hline Planning, development, implementation, operation and closure & Song et al. (2013) \\
\hline Raw material, product manufacturing, product distribution, use phase (stand by stage, use stage, maintenance stage) & Amaya et al. (2014) \\
\hline Planning, development, implementation, operation and closure & Lagemann et al. (2014) \\
\hline Conceptualization, use, service, maintenance, reuse, refurbishing, disposal & Herterich et al. (2015) \\
\hline Extraction, manufacture, transport, sales, installation, use, maintenance and disposal & Nemoto et al. (2015) \\
\hline 1deation, requirements, design, realization, delivery, support, evolution & Wiesner et al. (2015) \\
\hline
\end{tabular}

The PSS life cycle has been discussed in many publications, but the focus is predominantly in product-oriented solutions. PSS life cycle modeling for the other PSS categories is scarcely addressed. PSS business models can be classified into three main categories (Tukker, 2004): (i) product-oriented, (ii) use-oriented, and (iii) result-oriented. In the product-oriented category, the business focus is on the sale of products with some extra services. An example of this category is the Allegrini company, an Italian producer of detergents and cosmetics. It is a service that provides added value to the product life-cycle based on a home-delivery distribution of biodegradable and phosphorus-free detergents (United Nations Environment Programme, 2002). The consumers receive a kit of plastic flasks that can be filled up even if not completely empty. In the use-oriented category the traditional product 
still plays a central role, but it stays in ownership with the provider. Car-sharing system is one example of this type of PSS (Sundin et al., 2009). In the last category the consumer and the provider agree on a result; there is no pre-determined product involved. An example of this kind of PSS is 'selling' washed clothes (a result) instead of washing machines (Fan \& Zhang, 2010). Tukker (2004) also proposed subcategories for each main category.

In the use-oriented and result-oriented categories the service component is considered as the core part whilst physical products are only carriers for service delivery (Yang et al., 2010b; Zhu et al., 2012). Each category has a general life cycle of planning, development, implementation, operation and closure, which is determined by the phases of the established product/service phases (Song et al., 2013). Nevertheless, previous research has not provided the basis for each PSS category modeling and the differences in PSS development for each PSS category are scarcely discussed in the literature (Vasantha et al., 2012). In addition, PSS models must represent stakeholders, products, services, support systems, business elements and processes and interactions among them (Vasantha et al., 2012), but most of the existing approaches neglect to consider the system characteristics (Aurich et al., 2009).

From the existing publications, five life cycle phases were identified as essential for PSS categories. The life cycle proposed in this work was built taking into consideration the service life cycle from consumers' perspective (Yang et al., 2010a). This is important because most of the past research have not considered consumer and service providers' behavior in PSS modeling (Zhu et al., 2012).

The PSS life cycle should consider the BoL, MoL and Eol phases (Pezzotta et al., 2012). First, the PSS business opportunity is identified and the PSS idea is proposed. The consumers' needs and consumers requirements are identified and the system requirements should be identified in the context of each PSS, instead of isolated product or service (Marques et al., 2013). The PSS life cycle proposed starts with the systems requirements definition for the new PSS solution. From the requirements identification, the PSS can be developed, considering all the elements involved in the offer that are specific for each PSS type. Once the PSS is developed, the product-service can be produced or performed and made available to consumers (Marques et al., 2013). The implementation phase of PSS life cycle includes the operative realization of the PSS concept. The middle of life also includes the monitoring phase of PSS operation. PSS has to be supported to retain its functionality, availability, and results (Wiesner et al., 2015). The end of life addresses the PSS after it is used by consumers, including for instance documentation, replacement, recycling and product take-back (Zhu et al., 2012). According to the previous authors, some parts will be re-used in new products or kept as spare parts and the unusable parts will be recycled. If the PSS is not able to fulfill its intended application anymore, it enters the evolution stage (Wiesner et al., 2015).

Since PSS is systemic, it is necessary to check all stages of the life cycle continually. Feedback loops between phases should be taken into account but it is, most often, vaguely defined in the literature (Vasantha et al., 2012). Figure 1 illustrates the PSS life cycle proposed. The flow of materials returns as well as information and knowledge, allowing a continuous business improvement.

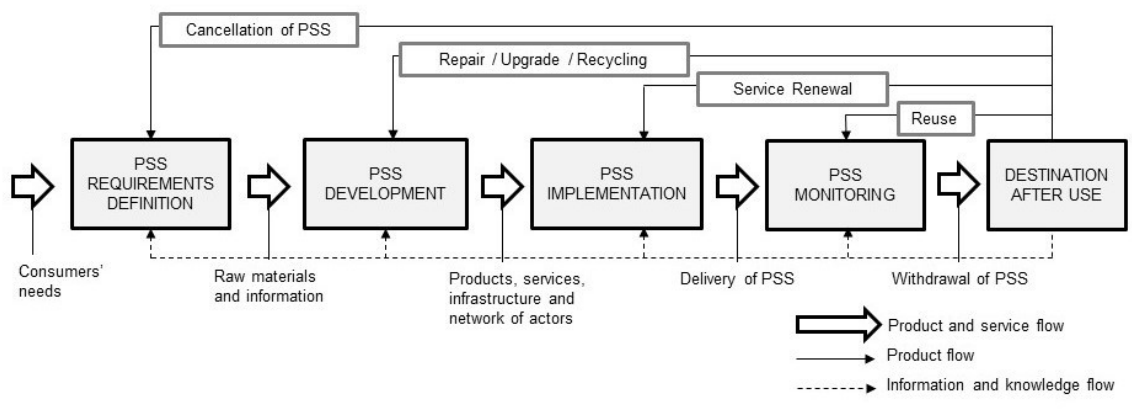

Figure 1. Proposed PSS life cycle.

Tran \& Park (2016) pointed out that PSS life cycle approaches need to consider phases such as idea development, planning, requirements analysis, concept development, design integration, testing and refinement, implementation and support, retirement and recycling and feedback loops. All these aspects were covered in the proposed life cycle phases and they are better described by the conceptual elements for each PSS life cycle phase presented next. 


\subsection{Identification of the conceptual elements in each life cycle phase}

Research in the engineering field is grounded in contributions whose main purpose is to define 'what' needs to be performed, and those elaborating 'how' to support each single activity (Cavalieri \& Pezzotta, 2012). In this research, the conceptual elements for PSS characterization (the 'hows') were identified from the PSS life cycle phases (the 'whats'). Specific characteristics for each PSS category were identified in the literature for each phase as well as by considering all PSS elements. Those characteristics were then transformed into information for PSS development. Many design methodologies have been discussed in the literature concerning what needs to be performed (e.g. Zhu et al., 2012; Tran \& Park, 2014; Moser et al., 2015; Wiesner et al., 2015), but they do not describe in details how to support each activity during the life cycle. Figure 2 shows the PSS life cycle proposed, and the basis adopted for the conceptual elements identification to support each life cycle phase, as already discussed in the research methods section.

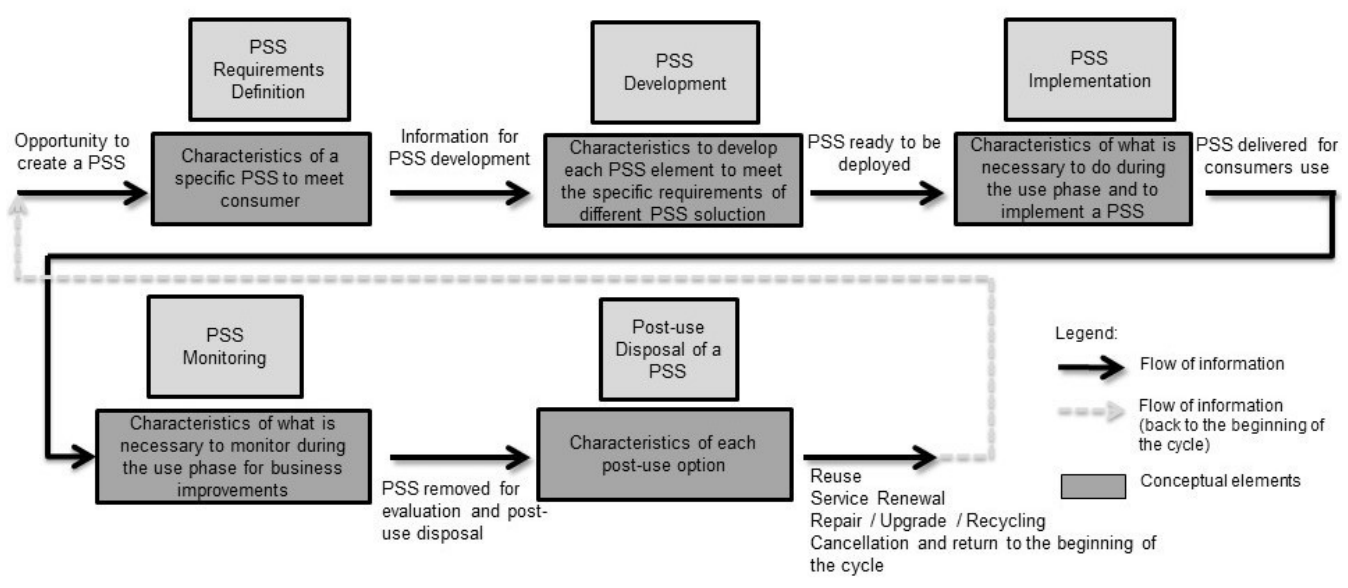

Figure 2. Basis for the identification of the conceptual elements from the input and output stages of the PSS life cycle.

Firstly, to create a new PSS, it is necessary to identify new opportunities. Consumers' needs become consumers' requirements (Alix \& Zacharewicz, 2012) and they provide opportunities to develop a new PSS. These opportunities for PSS idea creation can be different PSS business models. Depending on the identified opportunity, what will be offered should be planned and the system requirements that characterize each PSS solution may vary. In addition, to fulfill the needs of the consumers who will use a specific PSS it is necessary to identify the requirements of the system as a whole.

Indeed, how to develop a specific PSS is still scarce in the past research (Song et al., 2013). The publications, in general, do not discuss the PSS requirements in detail as they only mention it as one important life cycle activity. However, PSS requirements identification is crucial, it implies the definition of the requirements of the PSS solution to be developed according to the target market, and the definition of the best processes to support PSS development (Peruzzini et al., 2015). In this sense, the requirements for each PSS category considering all elements were identified, and they were transformed into conceptual elements for PSS characterization. These elements are shown in Table 3 and arranged according to each PSS category in Figure 3.

The requirements identification provides information for the development phase. To develop a PSS, it is necessary to plan the development of the products, services, actor's network and infrastructure as well as the relationship among them. The conceptual elements aim to specify what is necessary for the development of products, services, actors' network and infrastructure. The products should be developed to undergo changes in ownership as the provider becomes the owner of the product and responsible for the product during its life cycle. In addition, products must be planned to reduce the environmental impact at all stages of the PSS life cycle, in order to be a sustainable offer. Indeed, environmental aspects must be included as early as possible during the design process (Maussang et al., 2009).

In service development, service characteristics must be described, the processes for the conduction of the services should be defined as well as the resources use must be planned (Moser et al., 2015). The construction of an actor network plays an important role in the PSS design (Kimita \& Shimomura, 2014). The infrastructures 
Table 3. Conceptual elements for PSS requirements definition life cycle phase.

\begin{tabular}{|c|c|c|c|}
\hline $\begin{array}{l}\text { PSS } \\
\text { category }\end{array}$ & Conceptual elements & Description & References \\
\hline \multirow{11}{*}{ 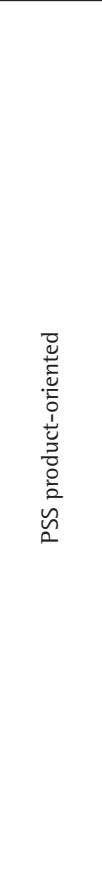 } & $\begin{array}{l}\text { Plan the acquisition of the } \\
\text { product with personalized services } \\
\text { (value proposition) }\end{array}$ & $\begin{array}{l}\text { In product-oriented PSS the providers are not responsible } \\
\text { for the product after the sale, but they are responsible for } \\
\text { providing personalized services }\end{array}$ & $\begin{array}{l}\text { United Nations Environment } \\
\text { Programme (2002) }\end{array}$ \\
\hline & $\begin{array}{l}\text { Plan the product property transfer } \\
\text { to consumer }\end{array}$ & $\begin{array}{l}\text { Plan the services offered during the product use in both } \\
\text { advising and consulting sub-categories }\end{array}$ & $\begin{array}{l}\text { Azarenko et al. (2009), Tukker } \\
\text { (2004) }\end{array}$ \\
\hline & $\begin{array}{l}\text { Plan the increase in product use } \\
\text { and life time }\end{array}$ & $\begin{array}{l}\text { Products need to be durable in order to reduce the resources } \\
\text { consumption and maintenance costs }\end{array}$ & Wu \& Gao (2010) \\
\hline & Plan the marketing model & $\begin{array}{l}\text { It is related to the definition of the offered services. It address } \\
\text { the activities to identify market requirements }\end{array}$ & Aurich et al. (2010) \\
\hline & $\begin{array}{l}\text { Plan the payment schemes for the } \\
\text { services performed }\end{array}$ & $\begin{array}{l}\text { When the consumer purchases the product it is necessary to } \\
\text { offer payment schemes options for the services offered }\end{array}$ & $\begin{array}{l}\text { United Nations Environment } \\
\text { Programme (2002) }\end{array}$ \\
\hline & $\begin{array}{l}\text { Plan the technical services (e.g. } \\
\text { maintenance) }\end{array}$ & $\begin{array}{l}\text { Periodic maintenance services based on consumers } \\
\text { requirements will be performed and the provider must plan it } \\
\text { focusing on workers with high levels of product knowledge } \\
\text { and relationship } \\
\text { development capability }\end{array}$ & Tukker (2004), Aurich et al. (2010) \\
\hline & $\begin{array}{l}\text { Plan consumers and suppliers } \\
\text { relationship }\end{array}$ & $\begin{array}{l}\text { It is necessary to plan the interactions with consumers and } \\
\text { suppliers }\end{array}$ & Aurich et al. (2010) \\
\hline & $\begin{array}{l}\text { Provide replacement materials to } \\
\text { the consumer }\end{array}$ & $\begin{array}{l}\text { The offer must be planned in order to periodically supply } \\
\text { consumers with the materials necessary for products use }\end{array}$ & Tukker (2004) \\
\hline & $\begin{array}{l}\text { Plan the service availability } \\
\text { (infrastructure) }\end{array}$ & $\begin{array}{l}\text { For consumer convenience, the services that complement the } \\
\text { product are offered in the consumer's preferred environment } \\
\text { in order to provide personalized services }\end{array}$ & $\begin{array}{l}\text { Tukker (2004), United Nations } \\
\text { Environment Programme (2002) }\end{array}$ \\
\hline & Result in economies of scale & $\begin{array}{l}\text { Plan the services in order to supply more than one consumer } \\
\text { and result in less costs and resources consumption }\end{array}$ & Wu \& Gao (2010) \\
\hline & $\begin{array}{l}\text { Provide consumer with } \\
\text { personalized services }\end{array}$ & $\begin{array}{l}\text { Personalized services ensure consumer loyalty by meeting } \\
\text { their needs continuously }\end{array}$ & Besch (2005) \\
\hline \multirow{14}{*}{ 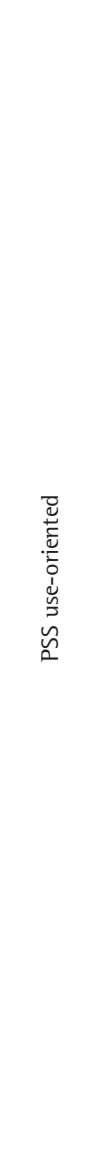 } & $\begin{array}{l}\text { Plan the use of the product } \\
\text { with personalized services (value } \\
\text { proposition) }\end{array}$ & Plan the function of the product to be offered & Sundin (2009), Aurich et al. (2010) \\
\hline & $\begin{array}{l}\text { Plan the increase in product use } \\
\text { intensity and life time }\end{array}$ & Create a durable product & Wu \& Gao (2010) \\
\hline & Plan payment for the used time & $\begin{array}{l}\text { In the second PSS category consumers use the product for a } \\
\text { pre-determined period of time and it is necessary to plan the } \\
\text { payment scheme }\end{array}$ & $\begin{array}{l}\text { Tukker (2004), United Nations } \\
\text { Environment Programme (2002) }\end{array}$ \\
\hline & Plan the marketing model & $\begin{array}{l}\text { It is related to the services offered. It provides activities to } \\
\text { identify and to address the market requirements }\end{array}$ & Aurich et al. (2010) \\
\hline & $\begin{array}{l}\text { Plan the product properties that } \\
\text { belong to service providers }\end{array}$ & $\begin{array}{l}\text { When the product cannot be used by consumers, the provider } \\
\text { identifies the appropriate destination for components and } \\
\text { materials }\end{array}$ & $\begin{array}{l}\text { Alix \& Zacharewicz (2012), Tukker } \\
\text { (2004) }\end{array}$ \\
\hline & $\begin{array}{l}\text { Plan the service delivery model } \\
\text { (lease, share or simultaneous use) } \\
\text { for high-value products }\end{array}$ & $\begin{array}{l}\text { It is necessary to create a lease system that consumers can } \\
\text { use products and services to meet their needs for an specific } \\
\text { period of time without acquiring them }\end{array}$ & $\begin{array}{l}\text { Aurich et al. (2010), Berkovich et al. } \\
\text { (2014), Besch (2005) }\end{array}$ \\
\hline & Plan individual product access & The product must be designed to be used individually & $\begin{array}{l}\text { Kang \& Wimmer (2008), } \\
\text { Aurich et al. (2010) }\end{array}$ \\
\hline & Plan the product share schemes & Different users share the same product at different times & $\begin{array}{l}\text { Aurich et al. (2010), Kang \& } \\
\text { Wimmer (2008) }\end{array}$ \\
\hline & $\begin{array}{l}\text { Plan the simultaneous use of the } \\
\text { product by different users }\end{array}$ & $\begin{array}{l}\text { Different consumers use the products and services at the } \\
\text { same time }\end{array}$ & $\begin{array}{l}\text { Kang \& Wimmer (2008), } \\
\quad \text { Aurich et al. (2010) }\end{array}$ \\
\hline & $\begin{array}{l}\text { Provide maintenance services, } \\
\text { repair, control and post-use } \\
\text { destination }\end{array}$ & $\begin{array}{l}\text { Plan the service performance before delivering a PSS to } \\
\text { consumers }\end{array}$ & $\begin{array}{l}\text { Alix \& Zacharewicz (2012), Besch } \\
\qquad \text { (2005) }\end{array}$ \\
\hline & $\begin{array}{l}\text { Guide the consumer on the } \\
\text { effective use of the product and } \\
\text { its environmental, social and } \\
\text { economic gains }\end{array}$ & $\begin{array}{l}\text { Consumers should be informed about product usage to } \\
\text { ensure adequate performance }\end{array}$ & Bastl et al. (2012) \\
\hline & $\begin{array}{l}\text { Offer on-site services or } \\
\text { consumer-based services }\end{array}$ & $\begin{array}{l}\text { Consumers often prefer to seek services and products that } \\
\text { meet their needs, and do not want to worry about the post- } \\
\text { purchase destination }\end{array}$ & $\begin{array}{l}\text { United Nations Environment } \\
\text { Programme (2002), Williams (2006) }\end{array}$ \\
\hline & Economies of scale & $\begin{array}{l}\text { To offer a service to more than one consumer increases the } \\
\text { product usability }\end{array}$ & Wu \& Gao (2010) \\
\hline & $\begin{array}{l}\text { Provide consumer with } \\
\text { personalized services }\end{array}$ & $\begin{array}{l}\text { Personalized service ensures consumer loyalty and that } \\
\text { consumer needs are met continuously }\end{array}$ & Besch (2005) \\
\hline
\end{tabular}


Table 3. Continued...

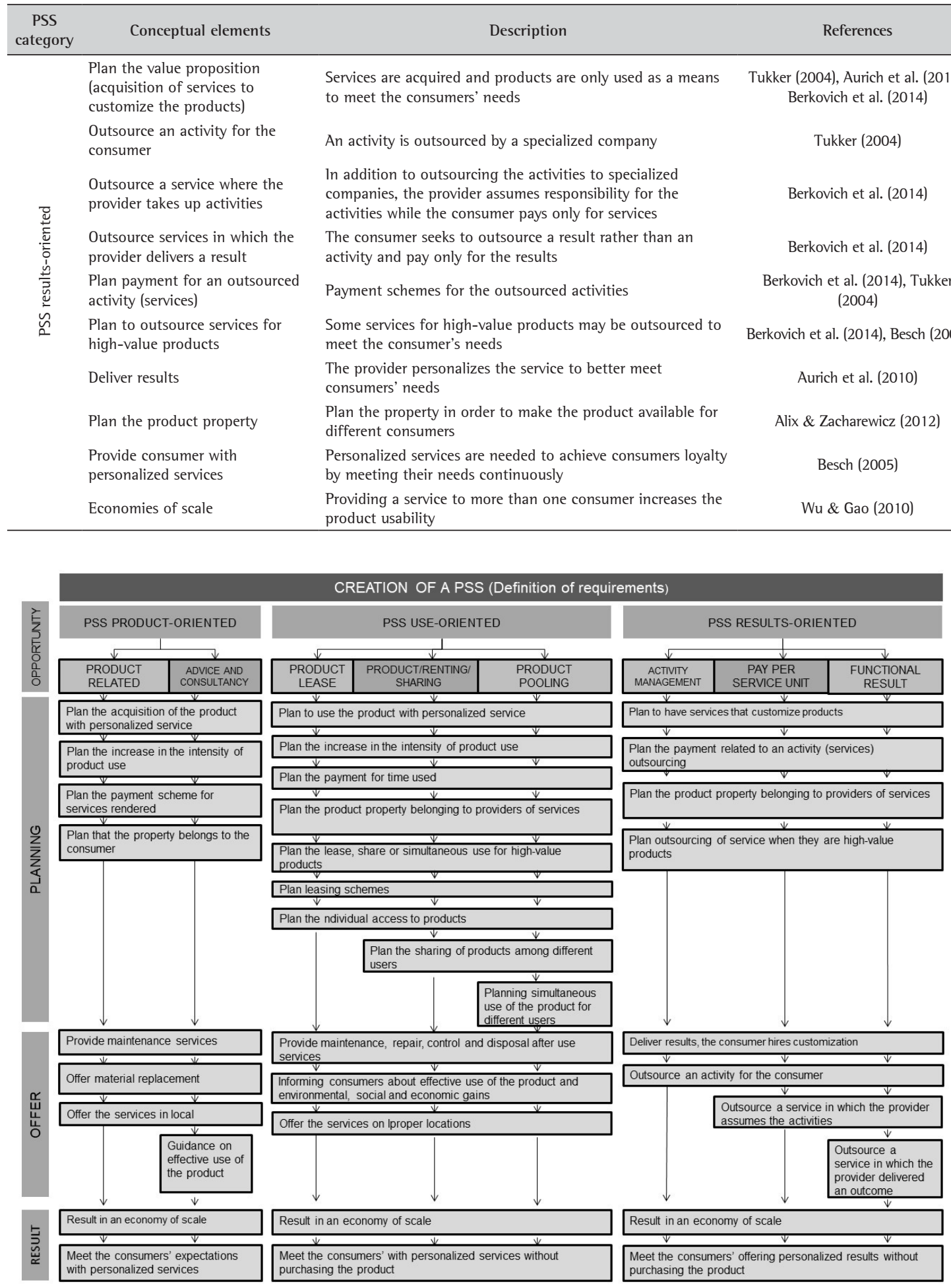

Figure 3. Organization of the conceptual elements in the first life cycle phase.

are referred to as dedicated infrastructures to PSS operation and need to be developed. Infrastructures and provider network are important components of PSS that affect consumer needs fulfillment (Lim et al., 2012). The conceptual elements for PSS development are shown in Table 4. 
Table 4. Conceptual elements for PSS development phase.

\begin{tabular}{|c|c|c|c|}
\hline $\begin{array}{l}\text { PSS } \\
\text { elements }\end{array}$ & Conceptual elements & Description & References \\
\hline \multirow{11}{*}{ 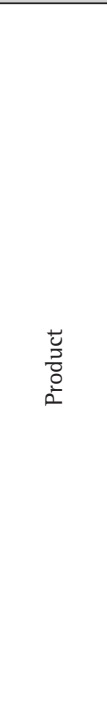 } & $\begin{array}{l}\text { Development products with low } \\
\text { environmental impact }\end{array}$ & $\begin{array}{l}\text { The products need to be planned to reduce the use of toxic } \\
\text { materials replacing them with renewable and recyclable materials }\end{array}$ & Sundin et al. (2010) \\
\hline & $\begin{array}{l}\text { Design products and components with } \\
\text { extended life }\end{array}$ & $\begin{array}{l}\text { When a product cannot be reused, repaired or upgraded, its } \\
\text { components should be recycled }\end{array}$ & $\begin{array}{l}\text { Tukker (2004), Vezzoli } \\
\qquad(2007)\end{array}$ \\
\hline & Design safe products & Products should be developed to be safe during the use phase & Mont \& Tukker (2006) \\
\hline & $\begin{array}{l}\text { Plan the use of local resources to } \\
\text { strengthen and enhance the region }\end{array}$ & Local resources should be considered when designing a product & Vezzoli (2007) \\
\hline & $\begin{array}{l}\text { Plan the products parts reuse (mainly } \\
\text { high-value parts) }\end{array}$ & $\begin{array}{l}\text { It is necessary to develop a take-back system to ensure that } \\
\text { products parts will return in good conditions }\end{array}$ & Besch (2005) \\
\hline & $\begin{array}{l}\text { Evaluation of the product at its final } \\
\text { destination (after use) }\end{array}$ & $\begin{array}{l}\text { The product will be used for long periods of time, it is necessary } \\
\text { to plan it for upgrading, reuse, disassembly and recycling }\end{array}$ & $\begin{array}{l}\text { Kuo \& Wang (2012), } \\
\text { Sundin et al. (2010), } \\
\text { Zhu et al. (2012) }\end{array}$ \\
\hline & $\begin{array}{l}\text { Design products in order to facilitate } \\
\text { its operation during the use }\end{array}$ & $\begin{array}{l}\text { The product should be designed for disassembly to facilitate the } \\
\text { exchange of parts, updates and material recycling }\end{array}$ & $\begin{array}{l}\text { Besch (2005), Sundin } \\
\text { (2009) }\end{array}$ \\
\hline & Design the product for durability & $\begin{array}{l}\text { To increase the life cycle of the product it is necessary that the } \\
\text { components have the same lifespan }\end{array}$ & Wang et al. (2011) \\
\hline & $\begin{array}{l}\text { Designing modularity and } \\
\text { standardization of parts }\end{array}$ & $\begin{array}{l}\text { Parts should be modular and standardized in order to facilitate } \\
\text { their replacement, product upgrades and repairs }\end{array}$ & $\begin{array}{l}\text { Wang et al. (2011), } \\
\text { Berkovich et al. (2014) }\end{array}$ \\
\hline & $\begin{array}{l}\text { Design a product with easy access to } \\
\text { components }\end{array}$ & The product should be modular and easy to disassemble & Sundin et al. (2010) \\
\hline & Design for disassembly & $\begin{array}{l}\text { The product should be designed for disassembly considering } \\
\text { materials that can be easily separated for reuse or recycling }\end{array}$ & Sundin et al. (2010) \\
\hline \multirow{6}{*}{ 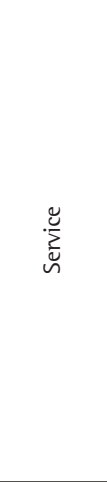 } & $\begin{array}{l}\text { Design services with low } \\
\text { environmental impact }\end{array}$ & $\begin{array}{l}\text { Services also should be planned to reduce the environmental } \\
\text { impacts, such as the maintenance services }\end{array}$ & Sundin et al. (2010) \\
\hline & $\begin{array}{l}\text { Design services to ensure product } \\
\text { safety }\end{array}$ & $\begin{array}{l}\text { The services must be designed to ensure the product safety } \\
\text { during the use }\end{array}$ & Besch (2005) \\
\hline & $\begin{array}{l}\text { Plan appropriate service networks to } \\
\text { meet the requirements of the different } \\
\text { PSS types }\end{array}$ & $\begin{array}{l}\text { The services must be compatible with the specifications of the } \\
\text { PSS project }\end{array}$ & Vogtlander et al. (2002) \\
\hline & $\begin{array}{l}\text { Plan the use of local services to } \\
\text { strengthen and enhance the region }\end{array}$ & $\begin{array}{l}\text { The use of local services can facilitate the logistics for the } \\
\text { service to be performed }\end{array}$ & Vezzoli (2007) \\
\hline & Support service for consumers & $\begin{array}{l}\text { Providers should build service facilities near major consumer } \\
\text { centers, for instance in the case of use-oriented and result- } \\
\text { oriented services. One possibility to achieve this is through } \\
\text { partnerships with local businesses }\end{array}$ & Bastl et al. (2012) \\
\hline & Design services & $\begin{array}{l}\text { The product and the service should be developed in an } \\
\text { integrated way }\end{array}$ & $\begin{array}{l}\text { Besch (2005), Kuo \& } \\
\text { Wang (2012) }\end{array}$ \\
\hline \multirow{7}{*}{ 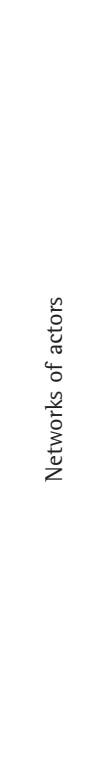 } & $\begin{array}{l}\text { Plan and monitoring the use of } \\
\text { resources with low environmental } \\
\text { impact }\end{array}$ & $\begin{array}{l}\text { It is important that all suppliers use a safe, durable materials, } \\
\text { with low environmental impacts }\end{array}$ & Vogtlander et al. (2002) \\
\hline & $\begin{array}{l}\text { Plan the interface between those } \\
\text { involved in the offer }\end{array}$ & $\begin{array}{l}\text { It is necessary to plan the interactions with consumers and } \\
\text { suppliers. This recurrent interaction with consumers facilitates } \\
\text { the deeper understanding of their needs, prolongs the } \\
\text { relationship between consumer and provider, and allows the } \\
\text { provision of more targeted solutions to consumers }\end{array}$ & $\begin{array}{l}\text { Bastl et al. (2012), } \\
\text { Aurich et al. (2010) }\end{array}$ \\
\hline & Plan partnerships & $\begin{array}{l}\text { To identify partners with greater expertise is important to ensure } \\
\text { the offer quality and also can facilitate consumer acceptance }\end{array}$ & $\begin{array}{l}\text { United Nations } \\
\text { Environment Programme } \\
\text { (2002) }\end{array}$ \\
\hline & $\begin{array}{l}\text { Plan the technical services in order } \\
\text { the technicians are located near the } \\
\text { consumers }\end{array}$ & This may allow a greater interaction during the use phase & $\begin{array}{l}\text { Aurich et al. (2006), } \\
\text { Bastl et al. (2012) }\end{array}$ \\
\hline & $\begin{array}{l}\text { Plan the qualification for the operators } \\
\text { and maintenance of their motivation }\end{array}$ & $\begin{array}{l}\text { The offer must be staffed by personnel who are flexible, } \\
\text { relationship-builders, service-centric, authentic, technically } \\
\text { adept, and resilient. Employees' satisfaction and motivation are } \\
\text { also important to PSS realization }\end{array}$ & $\begin{array}{l}\text { Aurich et al. (2010), } \\
\text { Kimita \& Shimomura } \\
\text { (2014) }\end{array}$ \\
\hline & Government incentives & $\begin{array}{l}\text { The government should be part of the network of actors for } \\
\text { the PSS in order to encourage acceptance. Government should } \\
\text { create new regulations and tax incentives that support the } \\
\text { necessary transition to PSS }\end{array}$ & Vogtlander et al. (2002) \\
\hline & $\begin{array}{l}\text { Design a PSS with consumer and other } \\
\text { stakeholders participation }\end{array}$ & $\begin{array}{l}\text { Developing PSS requires both the involvement of many } \\
\text { stakeholders who hold different views and the establishment of } \\
\text { a business model and organizational structure }\end{array}$ & $\begin{array}{l}\text { Tran \& Park (2014), } \\
\text { Kimita \& Shimomura } \\
\text { (2014) }\end{array}$ \\
\hline
\end{tabular}


Table 4. Continued...

\begin{tabular}{|c|c|c|c|}
\hline $\begin{array}{l}\text { PSS } \\
\text { elements }\end{array}$ & Conceptual elements & Description & References \\
\hline \multirow{4}{*}{ 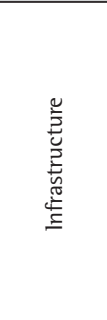 } & $\begin{array}{l}\text { Plan the all infrastructure (e.g. } \\
\text { technologies, devices, and spatial } \\
\text { layouts) necessary for PSS provision }\end{array}$ & $\begin{array}{l}\text { Any artifacts specifically required to provide } \\
\text { products and services need to be designed }\end{array}$ & Lim et al. (2012) \\
\hline & $\begin{array}{l}\text { Design of a system for communication } \\
\text { between those involved in the business }\end{array}$ & $\begin{array}{l}\text { The communication strategy should aim to facilitate the } \\
\text { distribution of information among stakeholders and consumers }\end{array}$ & Krucken \& Meroni (2006) \\
\hline & Plan the distribution chain & $\begin{array}{l}\text { The system should interact in all phases of the life cycle to } \\
\text { implement a closed-loop approach }\end{array}$ & Maxwell et al. (2006) \\
\hline & $\begin{array}{l}\text { Plan the PSS in accordance with the } \\
\text { local culture of the place where PSS } \\
\text { will operates }\end{array}$ & $\begin{array}{l}\text { The successful implementation of a PSS is highly dependent on } \\
\text { the culture in which it will operate, the infrastructure should be } \\
\text { well aligned with the characteristics of the region }\end{array}$ & Ceschin (2014) \\
\hline
\end{tabular}

After information on the development of a PSS and sales are consolidated, the PSS is then implemented. The conceptual elements for PSS implementation are important because the existing design methodologies have been facing challenges in providing guidelines for implementation (Tran \& Park, 2014). This phase involves PSS installation, tests, delivery and use, and successful implementation of PSS cases is important to encourage PSS adoption. The conceptual elements considered as essential in this phase are presented in Table 5, and they are suitable for all PSS categories.

Table 5. Conceptual elements for PSS implementation phase.

\begin{tabular}{|c|c|c|}
\hline Conceptual elements & Description & References \\
\hline Testing the product & $\begin{array}{l}\text { Tests are necessary to check the PSS during its operation; the service provider should ensure that } \\
\text { the product operates properly before allowing consumer use }\end{array}$ & $\begin{array}{l}\text { Moser et al. (2015), } \\
\text { Wiesner et al. (2015) }\end{array}$ \\
\hline Delivery & After tests are performed, the PSS can be delivered to the consumer as a package & Wiesner et al. (2015) \\
\hline Guidance to PSS use & It is necessary to guide consumers about the correct system usage, facilitating consumers acceptance & Morelli (2003) \\
\hline
\end{tabular}

In order to evaluate the solution after its implementation and during delivery to the consumers, it is fundamental monitoring the system (Pezzotta et al., 2015). The continuous monitoring of the system will allow a range of system improvements over the life cycle phases. Table 6 presents the conceptual elements for the PSS monitoring life cycle phase.

Table 6. Conceptual elements for PSS monitoring phase.

\begin{tabular}{|c|c|c|}
\hline Conceptual elements & Description & References \\
\hline $\begin{array}{l}\text { PSS monitoring during the } \\
\text { use phase }\end{array}$ & $\begin{array}{l}\text { During its operation, the PSS has to be supported to retain its functionality, } \\
\text { availability and results. By monitoring the PSS during use phase, product } \\
\text { maintenance can be performed before problems occur. Innovation is ensured by } \\
\text { monitoring the products in use }\end{array}$ & $\begin{array}{l}\text { Sundin et al. (2010), Kuo \& } \\
\text { Wang (2012), Wiesner et al. } \\
\text { (2015) }\end{array}$ \\
\hline Service delivery monitoring & $\begin{array}{l}\text { Delivery of a PSS contract is positively impacted by front-office staff who are humanistic } \\
\text { in their behavior, being skilled in flexibility, relationship building, service-centricity, } \\
\text { authenticity, resilience and technical aptitude, as this ensures speed and effectiveness } \\
\text { of response. Thus, monitoring the operation process may be valuable for business } \\
\text { improvement }\end{array}$ & Baines et al. (2013) \\
\hline $\begin{array}{l}\text { Knowledge accumulation } \\
\text { regarding PSS performance } \\
\text { during the use phase }\end{array}$ & $\begin{array}{l}\text { This is of great value for business improvement. A cost-effective assessment and } \\
\text { quality assessment need to be performed. In this stage, the system needs to meet } \\
\text { requirements with the objective of maximizing the product effectiveness at the } \\
\text { lowest cost, and also needs to take into account other requirements like serviceability, } \\
\text { reliability, maintainability and standardization }\end{array}$ & $\begin{array}{l}\text { Cook et al. (2006), } \\
\text { Zhu et al. (2012) }\end{array}$ \\
\hline $\begin{array}{l}\text { Feedback on consumer } \\
\text { expectations }\end{array}$ & $\begin{array}{l}\text { Consumer information is important to continuously improve existing PSS as well } \\
\text { as to develop new PSS. Key consumers often express their ideas and/or complaints } \\
\text { to the service provider. When information is returned to the company, a detailed } \\
\text { analysis of the market must be performed as well as the identification of a new set of } \\
\text { requirements }\end{array}$ & $\begin{array}{c}\text { Aurich et al. (2006), Alix \& } \\
\text { Zacharewicz (2012) }\end{array}$ \\
\hline
\end{tabular}

If a PSS is not able to fulfill its intended application anymore, it enters on the end of life cycle stage. This stage includes replacement, recycling, and/or product take-back (Zhu et al., 2012) and the product returns to the other PSS life cycles. The conceptual elements that characterize this phase of PSS life cycle are presented in Table 7. Next section outlines the main contributions of the paper. 
Table 7. Conceptual elements for PSS destination after the use phase.

\begin{tabular}{|c|c|c|}
\hline Conceptual elements & Description & References \\
\hline $\begin{array}{l}\text { The product returns to the provider and it is } \\
\text { the end of the service contract }\end{array}$ & The PSS is evaluated to perform improvements & Alix \& Zacharewicz (2012) \\
\hline Reparation & $\begin{array}{l}\text { The product is evaluated to verify if it is necessary } \\
\text { to repair it }\end{array}$ & Wu \& Gao (2010) \\
\hline Upgrade & $\begin{array}{l}\text { Product upgrade may occur due to technology } \\
\text { innovation }\end{array}$ & Yang et al. (2010b) \\
\hline Recycling of materials and parts & $\begin{array}{l}\text { The product must be designed to be recycled in } \\
\text { the end of life }\end{array}$ & United Nations Environment Programme (2002) \\
\hline
\end{tabular}

\section{Conclusions}

This paper introduces a framework to support PSS design by proposing a range of conceptual elements that need to be taken into consideration in each PSS life cycle stage. Since support frameworks are required to transfer information and knowledge from PSS life cycle to PSS conceptual design, this work aims to contribute to the body of knowledge. The proposed framework may allow to understand what should be done and how to perform the activities in PSS design considering different PSS types at a systemic level, meaning that the PSS design process takes into account all PSS elements: products, services, stakeholders, and infrastructure.

Many design approaches have been discussed in the literature considering the PSS life cycle, but in general, those approaches do not detail the life cycle stages at the level of different PSS categories. The PSS life cycle discussed in the literature is mainly focused on the development of product-oriented solutions, with few approaches discussing the life cycle for all PSS types and also considering the service life cycle from the consumer perspective.

In order to facilitate PSS transition and design process for practitioners, maximize PSS performance as well as to promote the implementation of PSS in practice, the proposed conceptual model can be taken as a promising starting point. For future work, the conceptual framework proposed will be applied to real PSS design process to evaluate if the conceptual elements are well aligned and to acquire practical insights for future improvements concerning the activities of each life cycle phase.

\section{References}

Alix, T., \& Zacharewicz, G. (2012). Product-service systems scenarios simulation based on G-DEVS/HLA: Generalized discrete event specification/high level architecture. Computers in Industry, 63(4), 370-378. http://dx.doi.org/10.1016/j.compind.2012.02.011.

Amaya, J., Lelah, A., \& Zwolinski, P. (2014). Design for intensified use in product-service systems using life-cycle analysis. Journal of Engineering Design, 25(7-9), 280-302. http://dx.doi.org/10.1080/09544828.2014.974523.

Aurich, J. C., Fuchs, C., \& Wagenknecht, C. (2006). Life cycle oriented design of technical Product-Service Systems. Journal of Cleaner Production, 14(17), 1480-1494. http://dx.doi.org/10.1016/j.jclepro.2006.01.019.

Aurich, J. C., Mannweiler, C., \& Schweitzer, E. (2010). How to design and offer services successfully. CIRP Journal of Manufacturing Science and Technology, 2(3), 136-143. http://dx.doi.org/10.1016/j.cirpj.2010.03.002.

Aurich, J. C., Wolf, N., Siener, M., \& Schweitzer, E. (2009). Configuration of product-service systems. Journal of Manufacturing Technology Management, 20(5), 591-605. http://dx.doi.org/10.1108/17410380910961000.

Azarenko, A., Roy, R., Shehab, E., \& Tiwari, A. (2009). Technical product-service systems: some implications for the machine tool industry. Journal of Manufacturing Technology Management, 20(5), 700-722. http://dx.doi.org/10.1108/17410380910961064.

Baines, T. S., Lightfoot, H. W., Evans, S., Neely, A., Greenough, R., Peppard, J., Roy, R., Shehab, E., Braganza, A., Tiwari, A., Alcock, J. R., Angus, J. P., Bastl, M., Cousens, A., lrving, P., Johnson, M., Kingston, J., Lockett, H., Martinez, V., Michele, P., Tranfield, D., Walton, 1. M., \& Wilson, H. (2007). State-of-the-art in product-service systems. Proceedings of the Institution of Mechanical Engineers. Part B, Journal of Engineering Manufacture, 221(10), 1543-1552. http://dx.doi.org/10.1243/09544054JEM858.

Baines, T., Lightfoot, H., Smart, P., \& Fletcher, S. (2013). Servitization of manufacture: exploring the deployment and skills of people critical to the delivery of advanced services. Journal of Manufacturing Technology Management, 24(4), 637-646. http://dx.doi. org/10.1108/17410381311327431.

Bastl, M., Johnson, M., Lightfoot, H., \& Evans, S. (2012). Buyer supplier relationships in a servitized environment: an examination with Cannon and Perreault's framework. International Journal of Operations \& Production Management, 32(6), 650-675. http://dx.doi. org/10.1108/01443571211230916.

Berkovich, M., Leimeister, J. M., Hoffmann, A., \& Krcmar, H. (2014). A requirements data model for product service systems. Requirements Engineering, 19(2), 161-186. http://dx.doi.org/10.1007/s00766-012-0164-1.

Besch, K. (2005). Product-service systems for office furniture: barriers and opportunities on the European market. Journal of Cleaner Production, 13(10-11), 1083-1094. http://dx.doi.org/10.1016/j.jclepro.2004.12.003.

Carreira, R., Patrício, L., Jorge, R. N., \& Magee, C. L. (2013). Development of an extended Kansei engineering method to incorporate experience requirements in product-service system design. Journal of Engineering Design, 24(10), 738-764. http://dx.doi.org/10. 1080/09544828.2013.834038. 
Cavalieri, S., \& Pezzotta, G. (2012). Product-Service Systems engineering: state of the art and research challenges. Computers in Industry, 63(4), 278-288. http://dx.doi.org/10.1016/j.compind.2012.02.006.

Ceschin, F. (2014). Product-service system innovation: a promising approach to sustainability. In F. Ceschin (Ed.), Sustainable productservice systems (Springer Briefs in Applied Sciences and Technology, pp. 17-40). Cham: Springer Verlag.

Cook, M. B., Bhamra, T. A., \& Lemon, M. (2006). The transfer and application of Product Service Systems: from academia to UK manufacturing firms. Journal of Cleaner Production, 14(17), 1455-1465. http://dx.doi.org/10.1016/j.jclepro.2006.01.018.

Fan, X., \& Zhang, H. (2010, May 13-14). Aligning product-service systems with market forces: a theoretical framework. In Proceedings of the 2010 International Conference on Service Sciences (pp. 110-114). Shanghai, China: 1CSS. http://dx.doi.org/10.1109/ICSS.2010.59.

Geng, X., Chu, X., Xue, D., \& Zhang, Z. (2010). An integrated approach for rating engineering characteristics' final importance in productservice system development. Computers \& Industrial Engineering, 59(4), 585-594. http://dx.doi.org/10.1016/j.cie.2010.07.002.

Herterich, M. M., Uebernickel, F., \& Brenner, W. (2015). The impact of cyber-physical systems on industrial services in manufacturing. Procedia CIRP, 30, 323-328. http://dx.doi.org/10.1016/j.procir.2015.02.110.

Kang, M. J., \& Wimmer, R. (2008). Product service systems as systemic cures for obese consumption and production. Journal of Cleaner Production, 16(11), 1146-1152. http://dx.doi.org/10.1016/j.jclepro.2007.08.009.

Kim, K. J., Lim, C. H., Heo, J. Y., Lee, D. H., Hong, Y. S., \& Park, K. (2016). An evaluation scheme for product-service system models: development of evaluation criteria and case studies. Service Business, 10(3), 507-530. http://dx.doi.org/10.1007/s11628-015-0280-3.

Kimita, K., \& Shimomura, Y. (2014). Development of the design guideline for product-service systems. Procedia CIRP, 16, $344-349$. http://dx.doi.org/10.1016/j.procir.2014.02.021.

Krucken, L., \& Meroni, A. (2006). Building stakeholder networks to develop and deliver product-service-systems: practical experiences on elaborating pro-active materials for communication. Journal of Cleaner Production, 14(17), 1502-1508. http://dx.doi.org/10.1016/j. jclepro.2006.01.026.

Kuo, T. C., \& Wang, M. L. (2012). The optimisation of maintenance service levels to support the product service system. International Journal of Production Research, 50(23), 6691-6708. http://dx.doi.org/10.1080/00207543.2011.616916.

Lagemann, H., Dorka, T., \& Meier, H. (2014). Evaluation of an IPS2 delivery planning approach in industry - limitations and necessary adaptations. Procedia CIRP, 16, 187-192. http://dx.doi.org/10.1016/j.procir.2014.01.021.

Lelah, A., Mathieux, F., \& Brissaud, D. (2011). Contributions to eco-design of machine-to-machine product service systems: the example of waste glass collection. Journal of Cleaner Production, 19(9-10), 1033-1044. http://dx.doi.org/10.1016/j.jclepro.2011.02.003.

Lim, C. H., Kim, K. J., Hong, Y. S., \& Park, K. (2012). PSS board: a structured tool for product-service system process visualization. Journal of Cleaner Production, 37, 42-53. http://dx.doi.org/10.1016/j.jclepro.2012.06.006.

Marques, P., Cunha, P. F., Valente, F., \& Leitão, A. (2013). A methodology for product-service systems development. Procedia CIRP, 7, 371-376. http://dx.doi.org/10.1016/j.procir.2013.06.001.

Maussang, N., Zwolinski, P., \& Brissaud, D. (2009). Product-service system design methodology: from the PSS architecture design to the products specifications. Journal of Engineering Design, 20(4), 349-366. http://dx.doi.org/10.1080/09544820903149313.

Maxwell, D., Sheate, W., \& van der Vorst, R. (2006). Functional and systems aspects of the sustainable product and service development approach for industry. Journal of Cleaner Production, 14(17), 1466-1479. http://dx.doi.org/10.1016/j.jclepro.2006.01.028.

Maxwell, D., \& van der Vorst, R. (2003). Developing sustainable products and services. Journal of Cleaner Production, 11(8), 883-895. http://dx.doi.org/10.1016/S0959-6526(02)00164-6.

Meier, H., Roy, R., \& Seliger, G. (2010). Industrial Product-Service Systems-IPS2. CIRP Annals-Manufacturing Technology, 59(2), 607627. http://dx.doi.org/10.1016/j.cirp.2010.05.004.

Mont, 0. (2002). Drivers and barriers for shifting towards more service-oriented businesses: analysis of the PSS field and contributions from Sweden. The Journal of Sustainable Product Design, 2(3), 89-103. http://dx.doi.org/10.1023/B:JSPD.0000031027.49545.2b.

Mont, O., \& Tukker, A. (2006). Product-Service Systems: reviewing achievements and refining the research agenda. Journal of Cleaner Production, 14(17), 1451-1454. http://dx.doi.org/10.1016/j.jclepro.2006.01.017.

Morelli, N. (2003). Product-service systems, a perspective shift for designers: a case study - the design of a telecentre. Design Studies, 24(1), 73-99. http://dx.doi.org/10.1016/S0142-694X(02)00029-7.

Moser, U., Maisenbacher, S., Kasperek, D., \& Maurer, M. (2015). Definition of an approach for the development of Product-Service Systems. Procedia CIRP, 30, 18-23. http://dx.doi.org/10.1016/j.procir.2015.02.130.

Nemoto, Y., Akasaka, F., \& Shimomura, Y. (2015). A framework for managing and utilizing product-service system design knowledge. Production Planning and Control, 26(14-15), 1278-1289. http://dx.doi.org/10.1080/09537287.2015.1033493.

Paré, G., Trudel, M., Jaana, M., \& Kitsiou, S. (2015). Synthesizing information systems knowledge: a typology of literature reviews. Information \& Management, 52(2), 183-199. http://dx.doi.org/10.1016/j.im.2014.08.008.

Peruzzini, M., Marilungo, E., \& Germani, M. (2015). Structured requirements elicitation for product-service system. International Journal of Agile Systems and Management, 8(3-4), 189-218. http://dx.doi.org/10.1504/1JASM.2015.073516.

Pezzotta, G., Cavalieri, S., \& Gaiardelli, P. (2012). A spiral process model to engineer a product service system: an explorative analysis through case studies. CIRP Journal of Manufacturing Science and Technology, 5(3), 214-225. http://dx.doi.org/10.1016/j.cirpj.2012.07.008.

Pezzotta, G., Pirola, F., Pinto, R., Akasaka, F., \& Shimomura, Y. (2015). A service engineering framework to design and assess an integrated product-service. Mechatronics, 31, 169-179. http://dx.doi.org/10.1016/j.mechatronics.2015.05.010.

Roy, R., \& Baxter, D. (2009). Product-service systems. Journal of Engineering Design, 20(4), 327-328. http://dx.doi.org/10.1080/09544820903149271.

Salazar, C., Lelah, A., \& Brissaud, D. (2015). Eco-designing product service systems by degrading functions while maintaining user satisfaction. Journal of Cleaner Production, 87, 452-462. http://dx.doi.org/10.1016/j.jclepro.2014.10.031.

Song, W., Ming, X., Han, Y., \& Wu, Z. (2013). A rough set approach for evaluating vague customer requirement of industrial productservice system. International Journal of Production Research, 51(22), 6681-6701. http://dx.doi.org/10.1080/00207543.2013.832435.

Sundin, E. (2009). Life-cycle perspectives of product/service-systems. In T. Sakao \& M. Lindahl (Eds.), Introduction to product/servicesystem design (pp. 31-49). London: Springer. 
Sundin, E., Lindahl, M., \& ljomah, W. (2009). Product design for product/service systems: design experiences from Swedish industry. Journal of Manufacturing Technology Management, 20(5), 723-753. http://dx.doi.org/10.1108/17410380910961073.

Sundin, E., Öhrwall Rönnbäck, A., \& Sakao, T. (2010). From component to system solution supplier: strategic warranty management as a key to efficient integrated product/service engineering. CIRP Journal of Manufacturing Science and Technology, 2(3), 183-191. http://dx.doi.org/10.1016/j.cirpj.2010.04.007.

Tran, T. A., \& Park, J. Y. (2014). Development of integrated design methodology for various types of product - service systems. Journal of Computational Design and Engineering, 1(1), 37-47. http://dx.doi.org/10.7315/JCDE.2014.004.

Tran, T., \& Park, J. Y. (2016). Development of a novel set of criteria to select methodology for designing product service systems. Journal of Computational Design and Engineering, 3(2), 112-120. http://dx.doi.org/10.1016/j.jcde.2015.10.001.

Tukker, A. (2004). Eight types of product-service system: eight ways to sustainability? Experiences from suspronet. Business Strategy and the Environment, 13(4), 246-260. http://dx.doi.org/10.1002/bse.414.

United Nations Environment Programme (2002). Product-service systems and sustainability: opportunities for sustainable solutions. Milan: INDACO Department/Politecnico di Milano. Retrieved in 2017, June 26, from http://www.unep.org/resourceefficiency/ Portals/24147/scp/design/pdf/pss-imp-7.pdf

Van Ostaeyen, J., Van Horenbeek, A., Pintelon, L., \& Duflou, J. R. (2013). A refined typology of product-service systems based on functional hierarchy modeling. Journal of Cleaner Production, 51, 261-276. http://dx.doi.org/10.1016/j.jclepro.2013.01.036.

Vasantha, G. V. A., Roy, R., Lelah, A., \& Brissaud, D. (2012). A review of product-service systems design methodologies. Journal of Engineering Design, 23(9), 635-659. http://dx.doi.org/10.1080/09544828.2011.639712.

Vezzoli, C. (2007). System design for sustainability: theory, methods and tools for a sustainable satisfaction-system design. Milan: Maggioli Edtore.

Vogtlander, J. G., Bijma, A., \& Brezet, H. C. (2002). Communicating the eco-efficiency of products and services by means of the ecocosts/value model. Journal of Cleaner Production, 10(1), 57-67. http://dx.doi.org/10.1016/S0959-6526(01)00013-0.

Wang, P. P., Ming, X. G., Li, D., Kong, F. B., Wang, L., \& Wu, Z. Y. (2011). Status review and research strategies on product-service systems. International Journal of Production Research, 49(22), 6863-6883. http://dx.doi.org/10.1080/00207543.2010.535862.

Wiesner, S., Freitag, M., Westphal, 1., \& Thoben, K. D. (2015). Interactions between service and product lifecycle management. Procedia CIRP, 30, 36-41. http://dx.doi.org/10.1016/j.procir.2015.02.018.

Williams, A. (2006). Product-service systems in the automotive industry: the case of micro-factory retailing. Journal of Cleaner Production, 14(2), 172-184. http://dx.doi.org/10.1016/j.jclepro.2004.09.003.

Wu, Y., \& Gao, W. (2010, Jan 9-10). A study on the model and characteristics of product-based service supply chain. In Proceedings of the International Conference on Logistics Systems and Intelligent Management (pp. 1127-1131). Harbin: ICLSIM. http://dx.doi. org/10.1109/1CLSIM.2010.5461134.

Yang, L., Xing, K., \& Lee, S. (2010a, March 17-19). Framework for PSS from Service' perspective. In Proceedings of the International Multiconference of Engineers and Computer Scientists (pp. 1656-1661) Hong Kong: IMECS.

Yang, L., Xing, K., \& Lee, S. (2010b, July 15-17). A new conceptual life cycle model for Result-Oriented Product-Service System development. Proceedings of the 2010 IEEE International Conference on Service Operations and Logistics, and Informatics (pp. 23-28). QingDao, China: IEEE. http://dx.doi.org/10.1109/SOLl.2010.5551621.

Zhang, L., Zhang, J., Duan, Z., \& Bryde, D. (2015). Sustainable bike-sharing systems: characteristics and commonalities across cases in urban China. Journal of Cleaner Production, 97, 124-133. http://dx.doi.org/10.1016/j.jclepro.2014.04.006.

Zhu, H., Gao, J., Li, D., \& Tang, D. (2012). A web-based product service system for aerospace maintenance, repair and overhaul services. Computers in Industry, 63(4), 338-348. http://dx.doi.org/10.1016/j.compind.2012.02.016. 